\title{
Optimization Pine Plantation Forest Management in Kediri FMU Regional Division II East Java
}

\author{
Andrie Ridzki Prasetyo"*, Muhamad Buce Saleh², Sudarsono Soedomo² \\ ${ }^{1}$ Graduate School of Bogor Agricultural University, Dramaga Main Road, Campus IPB Dramaga, Bogor, Indonesia 16680 \\ ${ }^{2}$ Department of Forest Management, Faculty of Forestry, Bogor Agricultural University, Academic Ring Road, Campus IPB \\ Dramaga, Bogor, Indonesia 16680
}

Received June 29, 2017/Accepted December 26, 2017

\begin{abstract}
Pine forest management today has not already reached its optimal state. The abnormal pine stand structure will cause a decrease in the production of pine resin. This study aimed to determine the optimal rotation of pine plantation forest and formulated the harvest scheduling to ensured optimal resin production. The determination of optimal rotation was conducted by modifying the Faustman formula to be applied on the condition in forest management in Perhutani. Simulation optimization of harvest scheduling was conducted by linear programming. Optimal rotation of pine forest plantation consists of timber rotation and resin rotation. The highest net present value of timber was obtained at 25 year cycles and the highest net present value of the resin was obtained at 35 year cycles. The inclusion of resin benefit was resulting in lengthening the optimal rotation age. The abnormal stand structure was causing the fluctuations of pine resin production. Thus, the efforts to improve it was by applying the harvest scheduling framework. This study concluded that harvest scheduling which conducted over eight periods has made the abnormal stand structure into the normal forest condition. The existence of normal forest condition led to the certainty of pine resin production sustainability.
\end{abstract}

Keywords: optimal rotation, normal forest, harvest scheduling, pine resin

*Correspondence author email : andrieridzki@gmail.com

\section{Introduction}

One of the utilization of Perhutani forest products is pine resin. Pine resin is a non-timber forest product that produced by the pine plantation forest (PPF). Based on its area, PPF is the second largest position after the teak plantation forest (Perhutani 2014). PPF produces pine resin, the raw material for the Turpentine Gondorukem Factory (PGT). Perhutani owns eight PGT and one PPCI derivate plant with 92,550 tons for production capacity. Pine resin processing contributes $30 \%$ from the total revenue of Perhutani (Perhutani 2014). The condition was illustrating that PPF management has the important role in the escalation of Perum Perhutani revenue. It has made Perum Perhutani constantly emphasizing the management of pine stands.

However, pine stands and pine resin production management have not reached the optimum state in the long run. It is indicated by the pine stand structure still exist at abnormal condition. PPF is dominated by old age class (KU VIII up) at 53\% (Perhutani 2015). Stacking the pine stand in the old age class will lead the degradation of resin production in the long-term. Some studies suggested that there were relation between age factor and resin production. Sudrajat et al. (2002) mentioned that the productivity of pine resin will decrease with increasing the stand age. In addition, Sukarno et al. (2012) studying the effect of age difference (KU) on pine resin productivity states that pine resin production among age class shows a marked difference. Resin

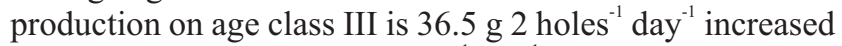

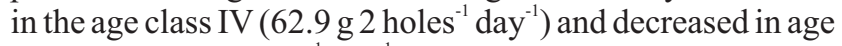
class V (24.6 g 2 holes $^{-1}$ day $\left.^{-1}\right)$.

Abnormal standing structure dominated by the old age class is due to the change in the rotation policy. The orientation of PPF management was initially directed to timber utilization. However, since the processing of pine resin into gondorukem and turpentine has high selling value and contributes $30 \%$ to total revenue of Perhutani (Sukardayanti 2014), there is a change of management orientation from wood to resin. Perum Perhutani through the Decree of the Directors Number 476/056.5/Can/Dir on 6th September 2001, changed the orientation from timber-based into a pine resin based by extending the 30 years old cycle to 50 years (Cahyono 2011). This policy appears to accommodate the high demand for the raw material supply of pine resin. However, review of Perhutani's research and development center in 2016 (Duta Rimba 2016) stated that the policy of determining pine rotation from $35-50$ years is 
not efficient anymore, field findings stated that pine stands over 34 years old are no longer productive. So many pine stand that have reached saturated tapping conditions but can not be felled because it has not reached the rotation. Delays in logging or regenerating stand cause an accumulation of standing structures in old age classes.

Determining when harvesting takes place or optimal rotation is an important component of forest resource management. The determination of the optimal rotation is based on the objectives of forest management (Bettinger et al. 2009). The study of the optimal rotation is a classic problem at the same time the oldest research that can be tracked in the context of natural resource economics (Amacher et al. 2009; Gong \& Lofgren 2009; Tahvonen 2009; Olschewski \& Benitez 2010; Soedomo 2012). Starting with Martin Faustmann's research in 1849 which laid the groundwork for studies related to optimal rotation determination (Chang 1998; Vittala 2013, 2016). Newman (2002) stated that since the late 1980s, the researcher's interest in the optimal harvesting problem in uncertainty has increased rapidly and various developments have been made. This phenomenon occurs since Samuelson (1976) shows that only Faustmann is analytically correct in the perspective of capital theory (Indrajaya \& Siarudin 2015). Various development and modification of the Faustmann formula is done to accommodate considerations of other aspects such as non-timber benefit, carbon sequestration, biodiversity, etc in determining optimal forest rotation (Gong \& Lofgren 2009; Nghiem 2014, 2015; Nguyen \& Nghiem 2016).

Related research about measuring the optimal rotation in Indonesia has been done frequently. Andayani (2006) studied the optimal financial rotation in KPH Pekalongan Barat by using methodology of land expectation value and CobbDouglas production function. Indrajaya (2013) examines the determination of the optimal financial rotation of Sengon stands using the Faustmann scenario. Indrajaya and Astana (2016) conducted a study on the optimal rotation. It was analysis of Gmelina stands on two carbon projects through Faustmann method that had modified for maximizing profits by sources of income from wood and carbon sequestration environmental services. These studies refer to the Faustmann scenario. The Faustmann scenario only applies on single even-aged trees, when a plot of land is simultaneously planted, cared for \& nurtured, harvested simultaneously, then replanted and the process is repeated (perpetual) indefinitely (infinite time) (Amacher et al. 2009; Tahvonen 2002; 2004; 2009). This condition is less appropriate to forest management scenarios in Perhutani which uses normal forest concept (Tahvonen \& Vittala 2006). The difference between the faustmann scenario and the normal forest scenario lies in the assumptions. The faustmann scenario only applies to stand level management conditions (Nghiem 2014). While normal forest scenarios apply to Forest level management conditions that consist of several age classes (Köthke \& Dieter 2010; Soedomo 2012; Nghiem 2014). Tahvonen and Vittala (2006) and Vittala (2016) stated the Faustmann approach is designed for stand-level management but it inherently does not meet assumptions and unable to solve the problem on multiple stand-level, forest level management, and regional level. The illustration of the differences in the Faustmann scenario and the normal forest scenario is presented in Figure 1.

The normal forests is an ideal concept in forest resource management (Bettinger et al. 2009). Normal forest indicates the sustainability on its annual results. Cumulation of stands on the old age class can lead to the declining of resin production in the long-term. Optimization of pine stands management can be conducted by conversion period approach. Conversion period in some scientific articles can be paired with the harvest scheduling. Hernandez et al. (2014) examined the harvest scheduling model by considering four contradictive research objectives. Factors that has taken into account in the study are abnormal standing structure conditions. Previous studies generally focus on harvest scheduling with major products are wood and carbon stocks (Bertomeu et al. 2009; Galatsidas et al. 2013; Tiryana 2016). This study was conducted on pine stands that have multiple benefits. Pine stands at the end of the rotation can produce the wood. In addition, starting at the age of 11 years until harvested, it will able to produce the pine resin. Research on harvest scheduling which the main objectives are maximizing the revenue of resin production based and maintaining the stability of pine resin production are still rare to be examined nowadays.

The optimization of forest management on PPF in this research is conducted in two phases, consist of re-examining the optimal rotation of pine stands and to fix the existing

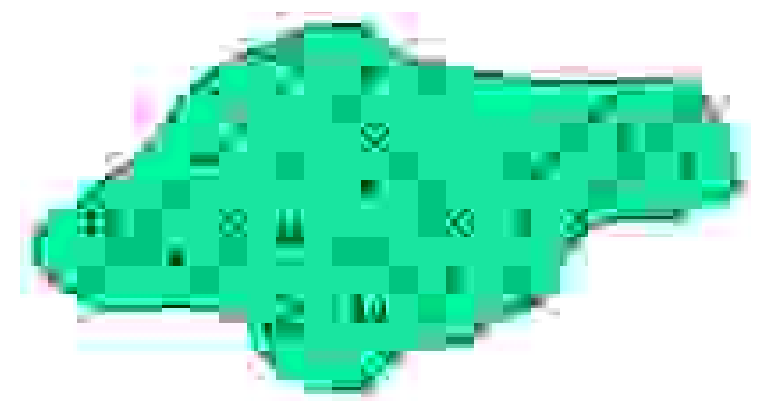

Figure 1 Illustration of differences in the Faustmann scenario (a) and normal forest scenario with a 15-year rotation example (b) 
standing structure in the harvest scheduling framework. Based on the description above, the objectives of this study are to determine the optimal financial rotation and to build the harvest scheduling model for PPF Kediri FMU.

\section{Methods}

Research location The research was conducted at KPH Kediri Perum Perhutani work area, regional division II in East Java. Geographically KPH kediri located E111 ${ }^{\circ} 23^{\prime} 58^{\prime \prime}-\mathrm{E} 111^{\circ} 39^{\prime} 44^{\prime \prime}$ and S6 $6^{\circ} 7^{\prime} 00^{\prime \prime}-\mathrm{S} 7^{\circ} 10^{\prime} 45^{\prime \prime} . \mathrm{KPH}$ Kediri is administratively comprised of 9 Sections of Forestry Unit (BKPH) which are divided into 7 parts of the forest. Five parts of the forest is a PPF whereas the other two parts are the teak plantation forest and the sengon plantation forest. Five parts of the forest include parts of Pace-Kediri forest, Tulungagung, Trenggalek, Kampak-Karangan, and Dongko. This research focused only on pine plantation forest.

Material and equipment The appropiate tools that used for this research are Microsoft Word, Microsoft Excel with Addin Solver, Curve Expert software, calculator, and normal yield table of ten industrial wood type (Suharlan et al. 1975). Normal yield table (Suharlan et al. 1975) is still relevant to be used by correction using inventory data of 2015. Inventory data has information about basal density (KBD) that used to correct the estimated volume of wood. This is reinforced by research Burrahman (2006) which states the use of KBD in estimating the volume of stands is still relevant to be done. The data used were obtained by study literature from Perhutani and other institution data. The data collected are inventory data on 2015 (containing information such as area, Bonita, and basal density), pine resin productivity data for each tapping plot, pine timber price 2015, pine resin price 2015 , and forest management cost realization report KPH Kediri Year 2015.

Stages of the workings Inventory data 2015 is the main reference on this research. The data contains information up to the plot level management. Each data contains information of area, site index, basal area (KBD), number of trees per hectare $\left(\mathrm{N} \mathrm{ha}^{-1}\right)$, year of planting, and type of plant to identify the initial stand structure. The study was conducted in two stages consist of determining the optimal rotation and restoring the stand structure to normal condition. Optimal rotation determination is done by modifying the faustmann formula so that compatible to be applied in Perhutani's condition (Soedomo 2012). Furthermore, developing the harvest scheduling model. It built by using Buongiorno and Gilles stand dynamics model (2003) which by linear programming. The results of model optimization shows the time period to improve the stand structure and the implications of the harvest scheduling.

Data analysis Data processing is conducted by several stages of analysis: the making of pine stand growth curve, the making of stand price estimation model on each age of stand, the making of resin yield function on every age. The analysis was conducted to support PPF revenue analysis. Furthermore, PPF financial management is analyzed. The revenue analysis and cost management analysis of PPF is implemented to determine the optimal rotation of PPF. The optimal rotation that obtained then applied on the harvest scheduling simulation optimization model.

Pine stands growth curve Timber yield projection is analyzed by making the growth curve of pine stands. The growth curve of pine stands is made using the normal table of Pine (Suharlan et al. 1975) and inventory data of 2015. Bonita used in estimating timber yield is a weighted average Bonita based on inventory data. The use of normal tables is done after information about the weighted average Bonita got. It will provide information about the normal volume. Furthermore, the obtained normal volume is multiplied by the average of basal density, then the volume will be obtained per year age of tree. Hence, it will forming the relation between age and volume of stands, as shown in Equation [1].

Average $K B D=\frac{\sum(L i \times K B D i)}{\uparrow L i}$

note: $\mathrm{KBDi}=$ average basal density in age class $\mathrm{i}, \mathrm{Li}=$ stand area with class $i$

Stand volume $=$ stand volume based on normal table $\times$ average $\mathrm{KBD}$

Pine resin yield equation model estimating the resin yield from pine stands was approached by resin harvesting data per each tapping plot in 2015. Based on the data, resin yield equations for each age of stands are made. Resin tapping begins when the age of 11-year-old pine stands. Realization data of resin harvesting is data that has considered various risks. The equation model as follows, as shown in Equation [2].

$G u=a+b u-c u^{2}$

note: $\mathrm{G} u=$ resin production at age $u\left(\mathrm{gram}^{-1}\right.$ tree $\left.^{-1} \mathrm{day}^{-1}\right), u=$ age of pine stands (year), a, b, and c = coefficient get from the data

Revenue analysis PPF's income is derived from t two products, timber and pine resin. Estimation of pine timber revenues are analyzed by inventory data 2015 , normal stand tables (Suharlan et al. 1975), and the timber price data in 2015. The timber price is sorted based on its timber diameter that standardized by normal stand table. Assumptions are used in the selection of timber quality that will affect the timber price. Due to the current PPF management orientation is to produce pine resin, so it is assumed that the timber quality obtained will not be optimal. The timber quality used is the weighted average timber quality. It is conducted to gain the price-weighted based on age of stands, not the constant price.

Estimation of revenue from resin are approximated by the resin realization data, normal stand tables (Suharlan et al. 1975), and the pine resin price 2015 . Resin production is approximated by the resin yield equation on each age. Thus, 
the pine resin production is multiplied with the pine resin price which has subtracted by the cost of production. So the price standard that prevailed is used to obtain the net profit.

Cost analysis Kediri FMU management cost data 2015 was the reference in this research. That data was the whole FMU management cost. The focus of analysis is PPF, so that the separation between other types of plantation forest management cost (other species) with PPF management cost in KPH Kediri was done. Separation is conducted based on the ratio between PPF and other types plantation forest. This management cost become as the standard cost of Kediri FMU in unit of rupiah $\mathrm{ha}^{-1}$.

Optimal rotation on pine plantation forest The optimal rotation determination of PPF was conducted by using the Faustmann formula with several modifications. Bettinger et al. 2009 states that the Faustmann formula is commonly used to estimate the land expectation value of a bare land to be simultaneously planted trees, cut down simultaneously, then replanted simultaneously with repeated (perpetual) processes indefinitely (infinite). The Faustmann formula is basically not for normal forest conditions. But it can be modified so it is suitable for use in forest management using normal forest concept.

Normal forest conditions are an $L$ hectare plot of land, which will not be planted simultaneously. However, that $L$ area is planted every year by $\mathrm{L} / \mathrm{T}$. Where $T$ is the determined optimal rotation (Soedomo 2012). $V(t)$ is the volume of stands per hectare on age $t . \quad p(t)$ is the average weighted timber price at age $t$. The cost of forest management is described by the notation $\mathrm{c}$ in units of IDR $\mathrm{ha}^{-1} . G(t)$ is the value of resin at age $t$. $R$ is a discount factor and $r$ is the real interest rate.

PPF has a management orientation as a producer of pine resin. Timber products are considered as by-products in the management of PPF. Optimal rotation determination is conducted by selecting $T$ which has the maximum NPV. The optimal rotation determination was performed on $\mathrm{NPV}_{\text {timber }}$, $\mathrm{NPV}_{\text {resin. }}$, and $\mathrm{NPV}_{\text {timber resin }}$. The equation that used as shown in Equation [3].

$$
\begin{aligned}
& N P V_{\text {timber }}=\left\{\frac{L}{T}\left\{p(t) V(t) e^{-r T}-c\right\} R\right. \\
& N P V_{\text {resin }}=\frac{L}{T}\left\{\int_{11}^{T} G(t) e^{-r T} d t\right\} R \\
& \left.N P V_{\text {timber+resin }}=\left\{\frac{L}{T} p(t) V(t) e^{-r T}-C\right\} R+\frac{L}{T}\left\{\int_{11}^{T} G(t) e^{-r T} d t\right\} R\right\} \\
& \text { With } R=1+\frac{1}{(1+r)}+\frac{1}{(1+r)^{2}}+\frac{1}{(1+r)^{3}}+\ldots+\frac{1}{(1+r)^{n-1}}
\end{aligned}
$$

note: $L=$ forest area (ha), $r=$ real interest rate, $T=$ optimal rotation (year), $c=$ forest management cost per hectar (IDR $\left.\mathrm{ha}^{-1}\right), p(t)=$ timber price on $t$ age (IDR ha- $), V(t)=$ stands volume per ha at $t$ age $\left(\mathrm{m}^{3} \mathrm{ha}^{-1}\right), R=$ discount factor, $G(t)=$ resin value at $t$ age (IDR ton ${ }^{-1} \mathrm{ha}^{-1}$ ).

Harvest scheduling simulation optimization simulations are formed to find out how long it takes to reach normal conditions and also forecasts of the financial implication that will be occurred when using the harvest scheduling. Improvement efforts can be interpreted as an attempt changing from the initial condition (which considered as a lack perform) to reach the expected condition (maximum results). Harvest scheduling model is created and modified with the framework used by Buongiorno and Gilles (2003). Models were adjusted according to the Perhutani's conditions. Components of the harvest scheduling model are consist of: initial conditions of the standing structure, harvest area, growth equation of the model, resin yield of every age class, pine resin price and management costs.

Harvest scheduling model is used for the production area. Like, age class I, age class II, ... then mature class forest. Bare land, TBK, LTJL, TKLR classes in the PPF are the priority for rehabilitation or planting. The initial condition of the pine stands structure is known based on inventory data 2015. The resin yield for each age class is derived from resin productivity data for each tapping plot. Based on that data, a resin yield equation is determined. Determination of conversion time $(t)$ is conducted as a prior. The scheduling is based on optimal pine rotation calculations.

Growth equations are formulated in such way that there is a dynamic change in the age class area in each period. The growth equation considers the damage factor of pine stands. Simulation optimization on harvest scheduling is done by linear programming (LP). LP provides many development opportunities as the main-tools for decision making to address the issue of natural resource management. The LP model is helpful to describe the economic implication between rotation length, conversion period for sustainable yield and NPV from the forest (Mohammadi et al. 2016).

Development of LP model is began by determining objective function, state variable, decision variable, constraint. The objective function of the model is to maximize NPV during the harvest scheduling period. State variables represents the structures of pine stands at each period/area of age class i in period $j$ (Aij). Decision variable describes the harvest area in age class $i$ in period $j$ (Xij). Harvest starts from age class VII up. Constraint that used are at the end of the harvest scheduling period there is no more age class VIII up (KU VIII up =0), at the end of the period has reached the steady state condition (even flow policy), non negativity constraint $\left(X_{i j}>0\right)$, the harvest area is less than the stock $(\mathrm{X} i j<\mathrm{A} i j)$, and the resin production in the initial period is smaller than the end of the conversion period. $\mathrm{A}_{\mathrm{ij}}=$ stock area at age class $i$ in period $j, \mathrm{X}_{\mathrm{ij}}=$ harvesting area at age class $i$ in period $j, \mathrm{~T}=\operatorname{period}(5$ year interval $)$

\section{Results and discussion}

Pine stands growth curve Timber yield estimation for each age is formed by making the growth curve of pine stands. The growth curve illustrates the relation between age and stand volume. The resulting curve in this research is logistic model. Navarrete and Bustos (2013) stated that the logistic model is able to represent well the sigmoid growth pattern of pine stands and produce more reliable estimates. The mathematical equations are as shown in Equation [4].

$y=236.972 /(1+39.60754 * \exp (-0.26686 x)$ 


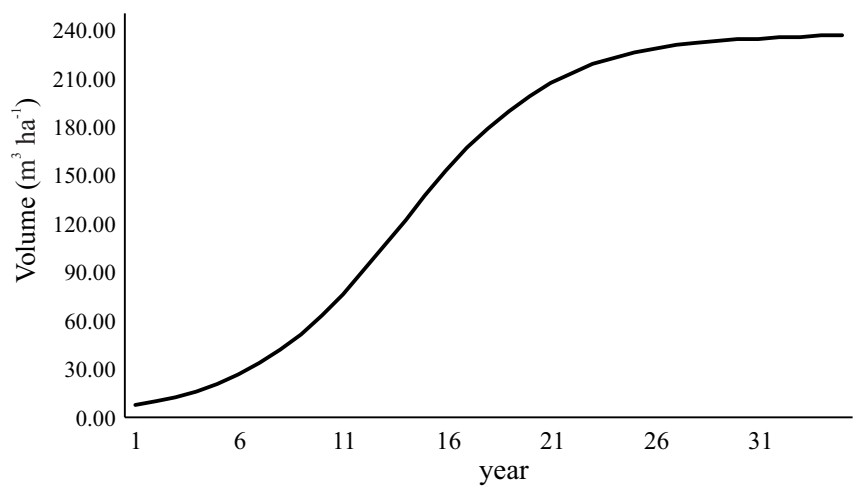

Figure 2 Growth curve of pine stands in research location.

Notation y represents the volume of pine stands in units of $\mathrm{m}^{3} \mathrm{ha}^{-1}$ and $x$ represents the age of pine stands in years. According to the growth curve, it showed that pine growth begins to slow down in the age post- 15 years. The growth curve of pine stands is shown in Figure 2. Based on the growth equation, biological rotation of pine stands can be identified. Biological rotation is when the current annual increment has the same value as mean annual increment or the time that gives the maximum production (Olschewski \& Benitez 2010; Indrajaya 2013). The biological rotation of pine stands in this study was at age 19.5 years.

Pine resin yield equation model Estimation of resin production is conducted by making the pine resin yield equation model. The pine resin yield equation is based on resin productivity data for each tapping plot in 2015. The mathematical equation of pine resin yield in this research is as shown in Equation [5].

$$
G u=5.98+0.36 u-0.00700 u^{2}
$$

note: $\mathrm{G} u=$ resin production at age $u\left(\right.$ gram tree $^{-1}$ day $\left.^{-1}\right), u=$ age of pine stands (year).

Pine tapping is done when the 11-year-old stand or age class III. Based on data processing it is seen that the productivity of resin is related to its age. The production of resin increases in the age class III to the age class $\mathrm{V}$ and begins to decrease after entering the age class VI (Figure 3 ). This is in line with Sudrajat et al. (2002) and Sukarno et al. (2012) which states relation on the different ages towards the resin productivity.

The result of data analysis showed the number of trees per hectare on average 160 trees $\mathrm{ha}^{-1}$ (Table 1). This amount is below the number of trees under normal conditions based on normal tables. Muis (2001) in his research found a relatively similar condition, which the number of field observation trees amounted to 330 trees ha ${ }^{-1}$ whereas only 180 trees ha $^{-1}$ were reported. The number of trees becomes important because the production that used to determine the optimal rotation is the production in units of $\operatorname{ton}^{-1} \mathrm{ha}^{-1} \mathrm{year}^{-1}$. This

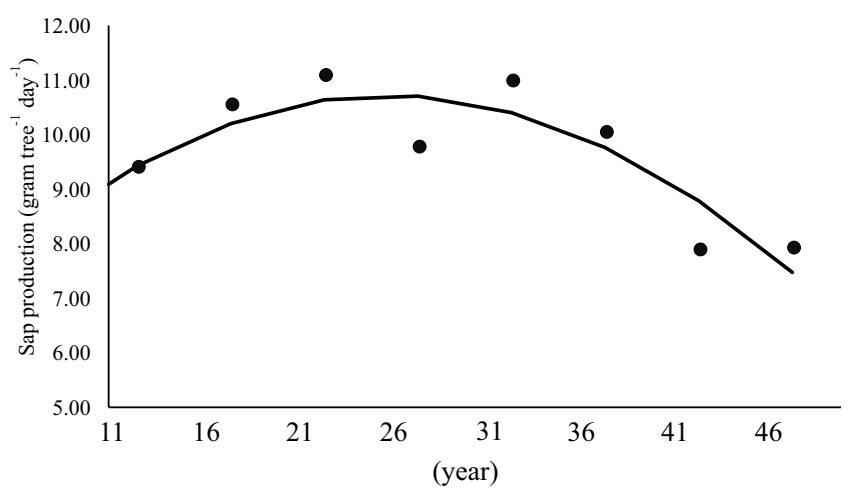

Figure 3 The tree productivity in producing pine resin by age.

argument then convinced by Wang et al. (2006) that the value of resin benefits is closely related to the number of trees per hectare so that thinning intensity needs more investigation.

Normal stand tables are made for the purpose of estimating the potential of wood under the normal conditions. Data analysis showed the usage of normal tree numbers in order to estimate the resin production will result declination of resin production $\left(\operatorname{ton}^{-1} \mathrm{ha}^{-1}\right.$ year $^{-1}$ ) dramatically on each age class (Figure 4). Normal stands table that intended for the purposes to to estimate the resin production are not available so far. Therefore, the assumption that used determining the number of trees $\mathrm{ha}^{-1}$ is conducted by plant spacing that will be used by Perhutani is $4 \mathrm{~m} \times 4 \mathrm{~m}(625$ trees $\mathrm{ha}^{-1}$ ). The stand damage was considered based on Wahyuni (2016), age class I - age class III 5\% and age class IVup 7\%. Based on these considerations the number of trees up to the oldest age class is above 300 trees $\mathrm{ha}^{-1}$. It became the reason on the selection of the number of trees per age class 300 trees $\mathrm{ha}^{-1}$. The usage of $300 \mathrm{ha}^{-1}$ trees for each age class gives a relatively the common pattern with the number of trees based on resin realization data (Figure 4).

PPF revenue analysis Timber yields projection that obtained through the growth curve then multiplied by the timber price. The timber price used is the weighted average timber price. It is due to the process of resin tapping that causing the timber quality tend to not reaching the optimum quality. Based on data analysis, we get the mathematical equation of timber price by age. The equation model as shown in Equation [6].

$$
y=20948 \ln (x)-181909
$$

The timber price is represented by $y$ at unit IDR $\mathrm{m}^{3}$ and the age of the pine stand is described by $x$ at unit years. Furthermore, the timber price is substracted by the cost of harvesting.

The projection of resin production that obtained through the resin yield equation is the production per tree per day. That value then multiplied by the number of trees based on the realization data and the number of tapping days in 1 year, 
Table 1 Recapitulations of pine resin production and tree number ha ${ }^{-1}$

\begin{tabular}{|c|c|c|c|c|c|c|c|c|}
\hline Note & KU III & KU IV & KU V & KU VI & KU VII & KU VIII & KU IX & KU X \\
\hline Production from realization data & 9.42 & 10.57 & 11.09 & 9.78 & 11.00 & 10.05 & 7.90 & 7.93 \\
\hline Middle age & 12.50 & 17.50 & 22.50 & 27.50 & 32.50 & 37.50 & 42.50 & 47.50 \\
\hline Production from equation & 9.43 & 10.20 & 10.61 & 10.68 & 10.40 & 9.77 & 8.78 & 7.45 \\
\hline Tree number $\left(\mathrm{n} \mathrm{ha}^{-1}\right)$ from realization data & 165.00 & 163.00 & 195.00 & 176.00 & 174.00 & 140.00 & 141.00 & 128.00 \\
\hline Production in tons ha $^{-1}$ year $^{-1}$ & 0.47 & 0.50 & 0.62 & 0.56 & 0.54 & 0.41 & 0.37 & 0.29 \\
\hline Tree number $\left(\mathrm{n} \mathrm{ha}^{-1}\right)$ from normal table & 488.00 & 351.00 & 268.00 & 216.00 & 188.00 & 167.00 & 159.00 & 159.00 \\
\hline Production in tons ha $^{-1}$ year $^{-1}$ & 1.38 & 1.07 & 0.85 & 0.69 & 0.59 & 0.49 & 0.42 & 0.36 \\
\hline Tree number $\left(300\right.$ tree $\left.\mathrm{ha}^{-1}\right)$ & 300.00 & 300.00 & 300.00 & 300.00 & 300.00 & 300.00 & 300.00 & 300.00 \\
\hline Production in tons ha $^{-1}$ year $^{-1}$ & 0.85 & 0.92 & 0.95 & 0.96 & 0.94 & 0.88 & 0.79 & 0.67 \\
\hline
\end{tabular}

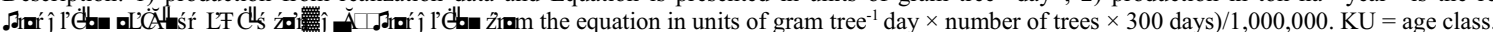

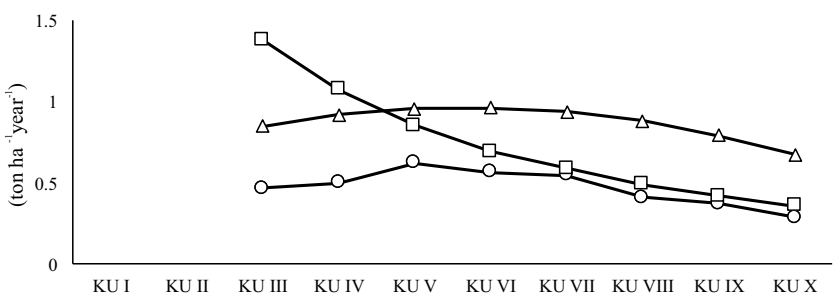

Figure 4 Production of pine resin in units of ton $\mathrm{ha}^{-1}$ year $^{-1}$ based on age class. Ton ha $^{-1}$ year $^{-1}$ realisasi $(-\infty)$, ton ha $^{-1}$ year $^{-1}(-\bullet)$, ton ha ${ }^{-1}$ year $^{-1}\left(300\right.$ tree ha $\left.^{-1}\right)(-\square)$. $\mathrm{KU}=$ age class.

thus it will get value in ton $\mathrm{ha}^{-1} \mathrm{day}^{-1}$. Income from resin is obtained by multiplying the resin production with the resin price. The price used is the net benefit that is derived after the resin price is subtracted by the cost of resin production.

Forest management cost Management of PPF Kediri FMU consists of activities that requires the cost from planning to until harvesting phase. Management costs for rotation determination in this study include planning, planting, maintenance, up to general and administrative costs. Harvesting costs are not included in the total cost of management because it had already incorporated into the timber price on revenue analysis. The costs that charged at each activity refer to the realization report of KPH Kediri forest management cost in 2015. Recapitulation of PPF forest management cost can be seen in Table 2 .

Optimal rotation determination Determination of PPF optimal rotation was conducted on the productive area of $28,185.8 \mathrm{Ha}$, forest management cost per hectare for all activities in one year amounted to IDR5,776,291.49, and real interest rate based on interest rate and inflation of Bank Indonesia in February 2017 by 1\%. Optimal rotation determination is done by specifying the appropriate time that gives the highest NPV.

Rotation determination is performed on two pine resin production conditions; Pine resin production based on realization data $(\mathrm{A})$ and pine resin production with the number 300 trees $^{-1}(\mathrm{~B})$. The results of data analysis showed that $\mathrm{NPV}_{\text {timber }}$ in these two conditions has the highest value on a 25 year rotation of IDR58,299,352,604.49. The $\mathrm{NPV}_{\text {resin }}$ at condition A has the highest value on 35 year rotation of IDR2 1,873,094,230.67 while condition $\mathrm{B}$ on 36 year rotation is IDR37.518.441.976.75. $\mathrm{NPV}_{\text {resintimber }}$ at condition $\mathrm{A}$ has the highest NPV on 26 years rotation of IDR78,446,907,613.28 whereas condition B has the highest NPV on 27 year rotation of IDR93,075,345,812.90. The NPV graph on both conditions can be seen in Figure 5.

The increasing of pine resin production will extends the optimal rotation and rises the $\mathrm{NPV}_{\text {resin }}$ and $\mathrm{NPV}_{\text {resint timber }}$ This is showed on the condition $\mathrm{A}$, where the maximum $\mathrm{NPV}_{\text {resin }}$ occurs at 35 years of rotation whereas in condition B that has a larger resin production, maximum $\mathrm{NPV}_{\text {resin }}$ is found in 36 year rotation. Based on data analysis, it is known that the addition of benefits from resin will extend the optimal rotation than if only considering the benefits just from timber only. This is consistent with Wang et al. (2006) research, inclusion the benefits of resin will lengthen the optimal rotation of PPF. Several previous studies were generally come into the similar conclusion, that the added benefit of non-timber, carbon, and biodiversity in the determination of optimal rotation will extend the optimal financial rotation (Olschewski \& Benitez 2010; Nghiem 2014; Indrajaya \& Siarudin 2015).

Data analysis shows that maximum production of pine resin at condition A occurs at 40-year rotation whereas at condition $\mathrm{B}$ occurs at $46-$ year rotation. The maximum pine resin production can be paired with maximum sustainable yield (MSY) term. Based on data processing, it is known that optimal rotation of pine resin is shorter than MSY rotation of pine resin. Similar findings were also raised by previous studies (Amacher et al. 2009; Indrajaya 2013). This condition influenced by using the pine resin constant price (price level). Olschewski \& Benitez (2010) says the optimal financial rotation will be shorter than MSY's rotation when using a constant price (price level).

Different conditions are found in timber rotation. Increase in price growth rate causes the rotation to be longer. It is also explained by Olschewski \& Benitez (2010) that the higher price growth will extend rotation and enable faustmann rotation longer than Maximum Sustainable Yield rotation. Nghiem (2014) stated that the use of timber price 
Table 2 PPF's forest management cost structure in Kediri FMU

\begin{tabular}{lc}
\hline \multicolumn{1}{c}{ Cost structure } & IDR $\mathrm{h}^{-1}$ \\
\hline Planning cost & 302.78 \\
Planting cost & $4,871,525.75$ \\
Maintenance and forest development cost & $560,803.97$ \\
Fire control and forest protection cost & $13,990.87$ \\
Costs fulfillment of financial obligations to the state, environment, and social & $69,543.31$ \\
Maintenance of facilities and infrastructure cost & $8,883.12$ \\
Other cutting wood production costs (more to the administration) & $169,535.14$ \\
Employee cost & $14,930.44$ \\
Cost of managing forest products & $1,856.52$ \\
General and administrative costs & $64,882.12$ \\
Other costs & 37.48 \\
Forest management costs & $5,776,291.49$ \\
\hline
\end{tabular}
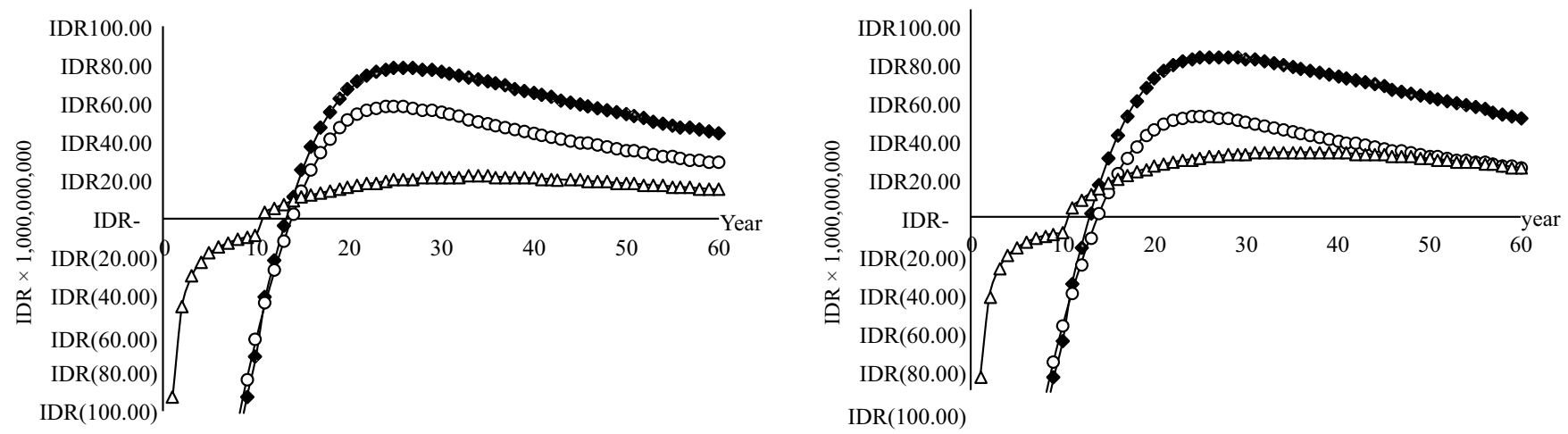

Figure 5 Pine plantation forest optimal rotation in Kediri FMU, NPV sap + wood $(\longrightarrow)$, NVP wood $(-0-)$, NPV sap $(\longrightarrow \triangle)$.

function on age will cause optimal rotation longer than using constant timber price. This result differs from the findings of Indrajaya and Siarudin (2015) because there are different types of prices used. Indrajaya and Siaruddin use the price level whereas in this study the authors use price growth.

Harvest scheduling simulation optimization The structure of pine stands in Kediri FMU is abnormal. The structure of the pine stands in period I (initial condition) accumulates in a bare land class (TK), KU II, and KU VIII (Figure 6). Improvement of standing structure is conducted by considering the orientation of PPF management as producer of pine resin. Based on the optimal rotation determination, NPV resin has the highest value on a 35 -year rotation (KU VII). Improvements are made within the framework of harvest scheduling so that at the end of the period a normal standing structure is formed with seven age classes. Harvest scheduling is formulated and operationalized by Linear Programming.

Based on the optimization simulation, it is known that the stand structure reaches normal in the eighth period or one rotation (Figure 6). The felling is still conducted with low intensity in period I and II due to the main focus is on planting in a bare land forest class. In the eighth and ninth period sustainability has been achieved with the same standing structure between the two periods. These findings are supported by previous studies which stated that to achieve the normal standing structures and provide stable results over time, it required one rotation (Davis et al. 2001; Bertomeu et al. 2009).

Simulation optimization of harvest scheduling is conducted by considering the stand damage factor. Stand damage causes the stand will able not to rise to the next age class, but going into the bare land forest class. This study 
used standing damage factor on each age class based on pine related research conducted by Wahyuni (2016). The initial stand structure was dominated by bare land as much as $22.23 \%$, KU II was $15.08 \%$, and KU VIII was $13.89 \%$ (Figure 7). The final period of harvest scheduling results a normal standing structure for seven age classes. Based on the consideration of the damage to stands, it is identified that the normal standing structure is not a stand structure that consists of an equally distributed age class. Figure 7 shows the final stand structure that fairly normal. This condition has similar pattern with the research of Tiryana (2016) which describes the final stand structure of the teak by considering the damage stand at the low level. Neither ideal nor perfect forest

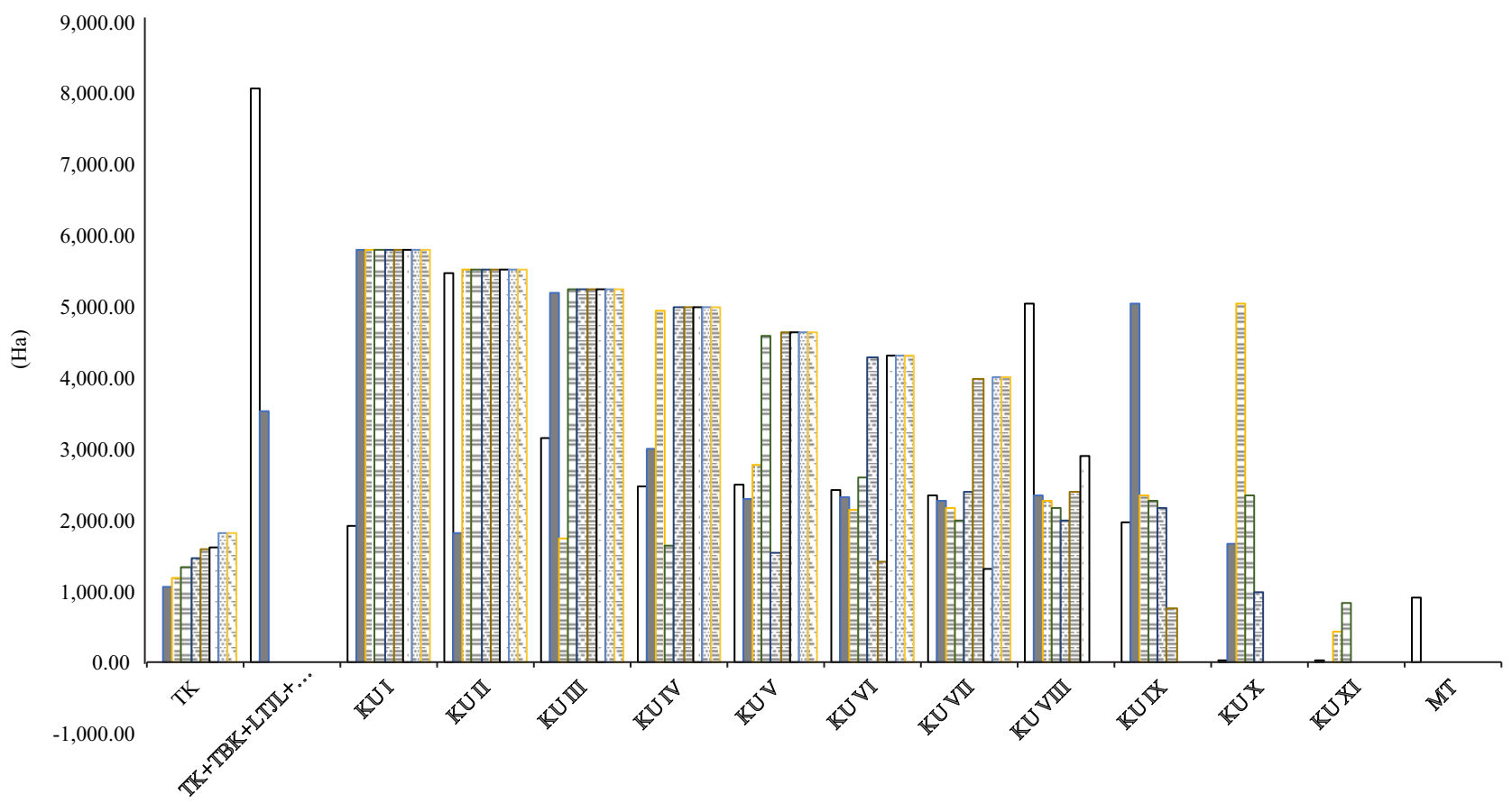

Figure 6 Dynamics of standing structures during harvest scheduling. Period $1(\square)$, Period $2(\square)$, Period $3(\Xi)$, Period 4 ( $\boxminus)$, Period 5

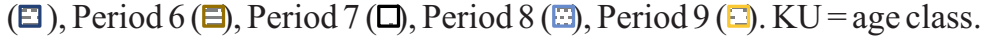
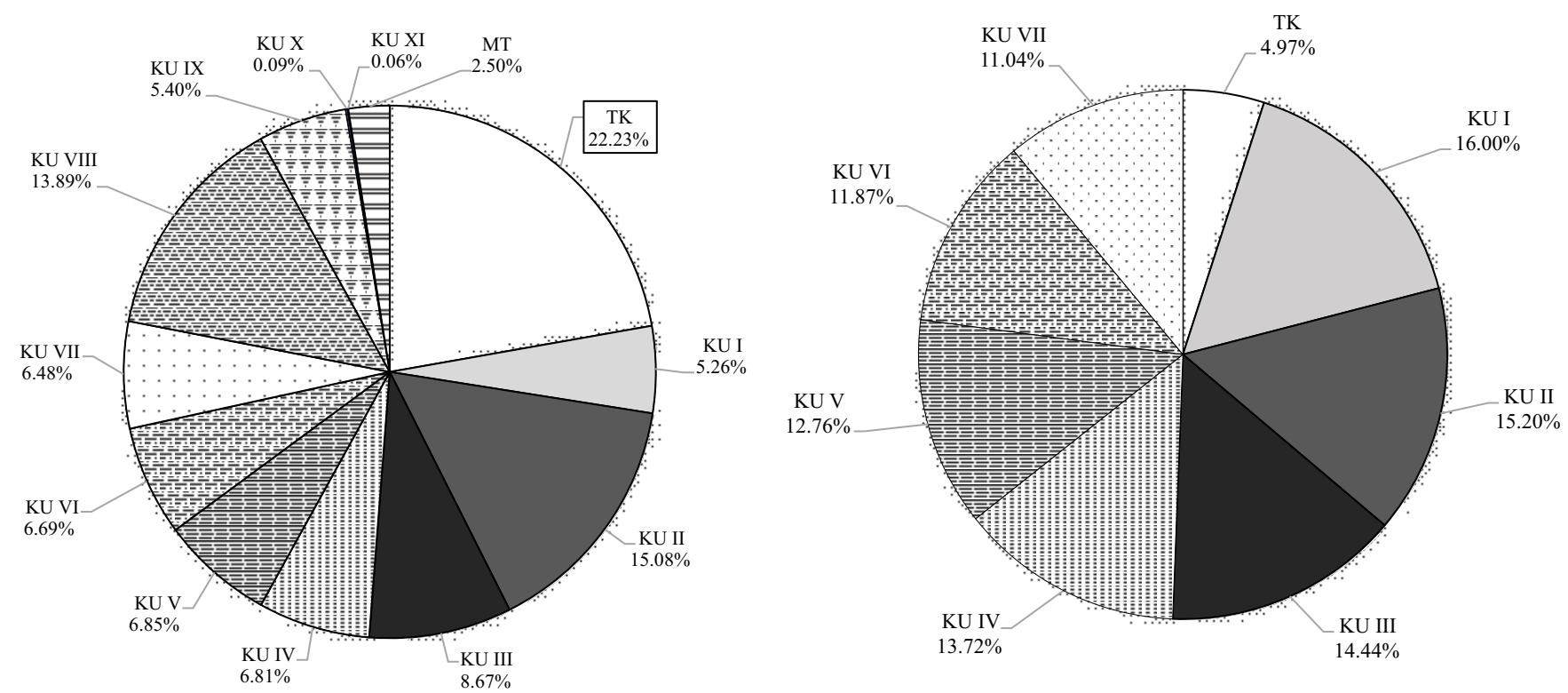

Figure 7 Initial stand structure (a) and ending stand structure (b) in PPF Kediri FMU. KU = age class. 
Table 3 Comparison of PPF management implications between harvest scheduling schemes and without harvest scheduling schemes scheduling period, this value will decrease if the simulation period is extended.

\begin{tabular}{lccr}
\hline \multicolumn{1}{c}{ Scheme } & $\begin{array}{c}\text { Pine resin production } \\
\text { (ton) }\end{array}$ & $\begin{array}{c}\text { Pine resin production at the end of } \\
\text { period (ton year }{ }^{-1} \text { ) }\end{array}$ & NPV (IDR) \\
\hline Harvest scheduling & $578,134.73$ & $12,390.29$ & $1,610,779,532,049.01$ \\
Without harvest scheduling & $542,580.80$ & $9,492.79^{\mathrm{b}}$ & normal \\
\hline
\end{tabular}

${ }^{\mathrm{a}}$ Production of pine resin during the harvest scheduling period ( 1 period $=5$ years $){ }^{\mathrm{b}}$ Annual pine resin production at the end of the harvest scheduling period, this value will decrease if the simulation period is extended.

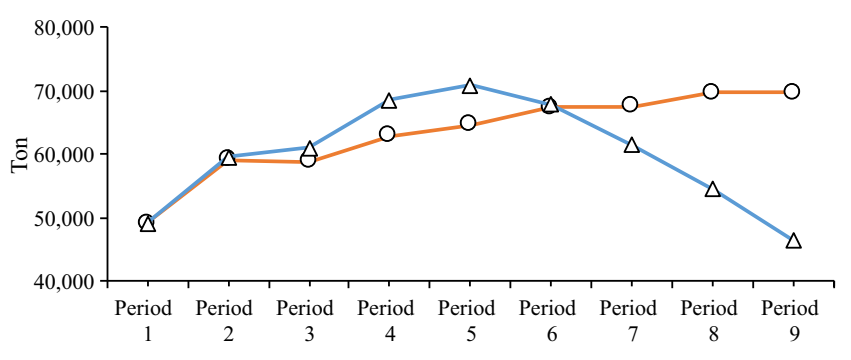

Figure 8 Projection of Kediri FMU resin production in two conditions. Harvest scheduling (- $(-)$ and without harvest scheduling $\left(\Delta^{-}\right)$.

conditions are very difficult to find in the real world due to natural disasters, pests, theft and so on (Bettinger et al. 2009; Rohman et al. 2013).

Stand structure condition affects the sustainability of pine resin production. Stand structure that accumulate in KU VIII up or abnormal standing structures in the long term will causing the fluctuations and decreasing pine resin productivity (Figure 8). Projection of pine resin production on condition without harvest scheduling in the initial five periods will give a larger production of $12,460.7$ tons compared to condition with harvest scheduling. However without harvest scheduling, after reaching the fifth period, pine resin productions is decreasing dramatically. Improvement of the standing structure will gradually increase the production pine resin (Figure 8). In addition, pine resin production will be stable at the end of the harvest scheduling when the forest stand structure reach normal conditions. Bettinger et al. (2009) stated that normal forest conditions gives implications toward the certainty of yield sustainability.

Table 3 shows that, reforming the stand structure through harvest scheduling results the greater pine resin production than without harvest scheduling. Applying harvest scheduling will provide better pine resin production (ton/year) than without harvest scheduling at the end of the period. Furthermore, the standing structure formed on the harvest scheduling scheme is a normal forest stand structure. In addition, the NPV obtained will be greater than without scheduling the harvest on the structure of the stand. Scenarios with harvest scheduling have greater NPV value due to additional benefits from timber sales. In this case, the benefits of timber are considered as a side benefit as a result of plant regeneration. The implications of normal forests on pine resin production are evident in the function of maintaining stability in production. Stable production will ensure the supply of raw materials for the processing industry owned by Perhutani. Abnormal standing structures have causing fluctuations towards pine resin production. The largest pine resin production occurs when the abnormal standing structure condition (when the stands accumulate in the productive tapping area). However, for the long term, this condition does not guarantee the sustained yield or certainty of raw material supply for the turpentine gondorukem industry. Meaning that in one period when compared with abnormal standing structures, it is likely to have a higher production than normal stand structures.. However, if looking at the long-term projection the normal stand structure is considered more satisfactory than the abnormal standing structure. Hahn et al. (2014) show advantages of sustained yield even-flow. They stated that even flows policy events that represented by normal stand structures will reduce the spread of risk and uncertainty in many ways.

\section{Conclusion}

Optimal rotation determination of PPF in Kediri FMU can be performed by modification of the Faustmann formula. The optimal rotation of PPF consists of the timber rotation and resin rotation. The highest NPV's timber is obtained on a 25-year rotation. The highest NPV's resin is obtained at 35 years of rotation. The addition of resin benefits will extend the optimal rotation. Abnormal standing structures causes fluctuations in resin production. Efforts to improve standing structures can be implemented by harvest scheduling frameworks that are formulated and operationalized in linear programming. Applying harvest scheduling will provide better pine resin production (ton year $^{-1}$ ) than without harvest scheduling at the end of the period. The NPV obtained from harvest scheduling will be greater than without harvest scheduling. Improvement of PPF stand structure can be conducted in eight periods. Normal forest conditions resulting the certainty of resin production sustainability.

\section{Acknowledgement}

I would like to express my sincere gratitude for management and staff of Kediri FMU for the support and assistance providing necessary data and document for this study. Valuable inputs and comments from anonymous reviewers are greatly appreciated. 


\section{References}

Amacher GS, Ollikainen M, Koskela E. 2009. Economics of forest resources. Cambridge: MITPress.

Andayani W. 2006. Analisis keuntungan pengusahaan hutan pinus (Pinus merkusii Jung et de Vriese) di KPH pekalongan Barat. Jurnal Manajemen Hutan Tropika 12(3):26-39.

Bertomeu M, Diaz-Balteiro L, Gimenez JC. 2009. Forest management optimization in Eucalyptus plantation: A goal programming approach. Canadian Journal of Forest Research 39:356-366. https://doi.org/10.1139/X08-173.

Bettinger P, Boston K, Sirey JP, Grebner D. 2009. Forest Management and Planning. Amsterdam: Academic Press.

Buongiorno J, Gilless JK. 2003. Decision Methods for Forest Resource Management. New York: Academic Press.

Burrahman M. 2006. Pengujian ketelitian penggunaan tabel tegakan pinus (Pinus merkusii Jungh. et de Vriese) di KPH Cianjur Perum Perhutani Unit III [undergraduate thesis]. Bogor: Bogor Agricultural University.

Cahyono SA. 2011. Faktor-faktor yang mempengaruhi petani menyadap pinus di kawasan hutan dengan tujuan khusus (KHDTK) Gombong. Tekno Hutan Tanaman 4(2):49-56.

Chang SJ. 1998. A generalized Faustmann model for the determination of optimal harvest age. Canadian Journal of Forest Research 28:652-659.

Davis LS, Johnson KN, Bettinger P, Howard TE. 2001. Forest Management: To Sustain Ecological, Economic, and Social Values. New York: McGraw Hill.

Duta Rimba. 2016. Iwan Gunawan: Mengkaji daur efektif tanaman pinus. Duta Rimba No. 62 tahun 11 JanuariFebruari:24-27. https://issuu.com/perhutani/docs/62-dredisi_62_jan-peb.

Galatsidas S, Petridis K, Arabatzis G, Kondos K. 2013. Forest production management and harvesting scheduling using dynamic linear programming (LP) models. Procedia Technology 8:349-354. https://doi.org/10.101/j.protcy. 2013.11.046.

Gong P, Löfgren KG. 2009. Modeling forest harvest decisions: advances and challenges. International Review of Environmental and Resource Economics 3(3):195-216. https://doi.org/10.1561/101.00000025.

Hahn WA, Härtl F, Irland LC, Kohler C, Moshammer R, Knoke T. 2014. Financially optimized management planning under risk aversion results in even-flow sustained timber yield. Forest Policy and Economics 42:30-41. https://doi.org/10.1016/j.forpol.2014.02.002.

Hernandez M, Gómez T, Molina J, León MA, Caballero R. 2014. Efficiency in forest management: A multiobjective harvest scheduling model. Journal of Forest Economics 20(3):236-251.https://doi.org/10.1016/j.jfe.2014.06.002

Indrajaya Y. 2013. Penentuan daur optimal hutan tanaman sengon (Paraserianthes falcataria (L.) Nielsen) dengan metode Faustmann. Jurnal Penelitian Agroforestry 1(1):31-40.

Indrajaya Y, Siarudin M. 2015. Pengaturan hasil agroforestry jabon (Neolamarckia cadamba Miq.) dan kapulaga (Amomum Compactum) di Kecamatan Pakenjeng Garut Jawa Barat. Jurnal Penelitian Sosial dan Ekonomi Kehutanan 12(2):121-130.

Indrajaya Y, Astana S. 2016. Daur optimal tegakan gmelina pada dua proyek karbon: Memperpanjang daur dan aforestasi. Jurnal Penelitian Sosial dan Ekonomi Kehutanan 13(3):145-154.

Köthke M, Dieter M. 2010. Effects of carbon sequestration rewards on forest management-An empirical application of adjusted Faustmann Formulae. Forest Policy and Economics 12:589-597. https://doi.org/10.1016/j.forpol. 2010.08 .001

Navarrete E, Bustos J. 2013. Faustmann optimal pine stands stochastic rotation problem. Forest Policy and Economics 30:39-45. https://doi.org/10.1016/j.forpol.2013.02.007.

Newman DH. 2002. Forestry's golden rule and the development of the optimal forest rotation literature. Journal of Forest Economics 8(1):5-27. https://doi.org/ 10.1078/1104-6899-00002.

Nghiem N. 2014. Optimal rotation age for carbon sequestration and biodiversity conservation in Vietnam. Forest Policy and Economics 38:56-64. https://doi.org/10.1016/j.forpol. 2013.04.001.

Nghiem N. 2015. Optimal forest management for timber value and carbon sequestration benefits in tropical planted forests: a case study of household foresters in Vietnam. Environment and Development Economics 20(6):746-766. https://doi.org/10.1017/S1355770X140 00680 .

Nguyen TT, Nghiem N. 2016. Optimal forest rotation for carbon sequestration and biodiversity conservation by farm income levels. Forest Policy and Economics 73:185-194. https://doi.org/10.1016/j.forpol.2016.09. 014.

Mohammadi Z, Limaei SM, Shahraji TR. Linear programming approach for optimal forest plantation. Journal of Forestry Research 28(2):299-307. https://doi.org/10.1007/s11676-016-0318-y.

Muis ZZ. 2001. Prospek pengembangan industri pengolahan getah pinus untuk wilayah KPH Sukabumi, KPH Cianjur dan KPH Bogor [thesis]. Bogor: Bogor Agricultural University. 
Olschewski R, Benitez PC. 2010. Optimizing joint production of timber and carbon sequestration of afforestation projects. Journal of Forest Economics 16:1-10. https://doi/org/10. 1016/j.jfe.2009.03.002.

Perum Perhutani. 2014. Annual Report Perum Perhutani Tahun 2014. Jakarta: Perhutani.

Perum Perhutani. 2015. Statistik Perum Perhutani Tahun 2010-2014. Jakarta: Perhutani.

Rohman, Warsito SP, Purwanto RH, Supriyatno N. 2013. Normalitas tegakan berbasis resiko untuk pengaturan kelestarian hasil hutan tanaman jati di Perum Perhutani. Jurnal Ilmu Kehutanan 7(2):81-92.

Salo S, Tahvonen O. 2002. On the optimality of a normal forest with multiple land classes. Forest Science 48(3):530-542.

Soedomo S. 2012. Internalizing externalities through payments for environmental services. Jurnal Manajemen Hutan Tropika 18(2):138-143. https://doi.org/10.7226/ jtfm.18.1.138.

Sudradjat R, Setyawan D, Sumadiwangsa S. 2002. Pengaruh diameter pohon, umur dan kadar stimulan terhadap produktivitas getah tusam. Buletin Penelitian Hasil Hutan 20(2):143-158.

Suharlan A, Sumarna K, Sudiono J. 1975. Tabel tegakan sepuluh jenis kayu industri. Bogor: Pusat Penelitian dan Pengembangan Hutan.

Sukadaryati. 2014. Formulasi strategi kebijakan penggunaan stimulansia ramah lingkungan dalam produksi getah pinus di Perum Perhutani [dissertation]. Bogor: Bogor Agricultural University.

Sukarno A, Hardiyanto EB, Marsoem SN, Na'iem M. 2012. Pengaruh perbedaan kelas umur terhadap produktivitas getah Pinus Merkusii Jungh et de Vriese ras lahan jawa melalui penyadapan getah metode bor. Jurnal Pembangunan dan Alam Lestari 3(1):28-31.

Tahvonen O. 2004. Optimal harvesting of forest age classes: A survey of some recent result. Mathematical Population Studies: An International Journal of Mathematical Demography 11:205-232. https://doi.org/10.1080/ 08898480490513616

Tahvonen O, Viitala EJ. 2006. Does Faustmann rotation apply to fully regulated forests? Forest Science 52 (1):23-30.

Tahvonen O. 2009. Optimal choice between even- and unevenaged forestry. Natural Resource Modeling. 22(2):289-321. https://doi.org/10.1111/j.19397445.2008. 00037.x.

Tiryana T. 2016. Simulating harvest schedule for timber management and multipurpose management in teak plantations. Jurnal Manajemen Hutan Tropika 22(1):1-12. https://doi.org/10.7226/jtfm. 2.1.1.

Viitala EJ. 2013. The discovery of the faustmann formula in natural resource economics. History of Political Economy 45(3):523-548. https://doi.org/10.1215/001827022334785

Viitala EJ. 2016. The emergence and early development of forest resource economic thought: From land and forest valuation to marginal analysis and vintage capital models [dissertation]. Helsinki: University of Helsinki.

Wahyuni M. 2016. Model simulasi pengusahaan hutan pinus di KPH Bondowoso Perum Perhutani divisi regional jawa timur [undergraduate thesis]. Bogor: Bogor Agricultural University.

Wang Z, Calderon MM, Carandang MG. 2006. Effects of resin tapping on optimal rotation age of pine plantation. Journal of Forest Economics 11:245-260. https://doi.org/10.1016/j.jfe.2005.10. 001. 